\title{
Implementation of the Internal Quality Assurance System at UIN Malang Indonesia
}

\author{
Mulyono $^{\mathrm{a}}$, Asmaun Sahlan ${ }^{\mathrm{b}}$, Tutut Sholihah $^{\mathrm{c}}$, Diah Rusmingsih $^{\mathrm{d}}$, Efy Setiawati Atanjuani $^{\mathrm{e}}$ \\ ${ }^{a}$ UIN Maulana Malik Ibrahim Malang, Jalan Gajayana No. 50 Malang Indonesia (ORCID: 0000-0002-4509- \\ 7390) \\ ${ }^{\mathrm{b}}$ UIN Maulana Malik Ibrahim Malang, Jalan Gajayana No. 50 Malang Indonesia \\ ${ }^{\mathrm{c}}$ IAIN Palangkaraya, Jalan G. Obos, Palangkaraya, 74874 Indonesia \\ d STIEKN Jaya Negara Tamansiswa Malang, Jalan R. Tumenggung Suryo No.17 Malang 65123, Indonesia \\ ${ }^{\mathrm{e}}$ UIN Maulana Malik Ibrahim Malang, Jalan Gajayana No. 50 Malang Indonesia
}

Article History: Received: 11 January 2021; Accepted: 27 February 2021; Published online: 5 April 2021

\begin{abstract}
This study aims to examine the implementation of the internal quality assurance system (IQAS) at the State Islamic University of Maulana Malik Ibrahim Malang Indonesia (called UIN Malang). This research uses qualitative methods, data obtained through interviews, document review and observation, and data analysis techniques using interactive analysis models. The results of the research can be concluded as follows: 1) The University established a Quality Assurance Institute (QAI) at the university level, the Quality Assurance Unit (QAU) at the Faculty level, Postgraduate Program, Language Development Center, and Ma'had (campus dormitories) and Quality Control Groups (QCG) at the Department/Study Program level. 2) Compiling quality assurance system planning in documents: quality policy, quality manual, quality standards, quality forms, monitoring, measurement and self-evaluation, internal quality audits, and Management Review Meetings (MRM). 3) Applying the PDCA (Plan, Do, Check, Action) model which is the application of Total Quality Management (TQM) to produce a cycle of continuous quality improvement. 4) Establish idealized academic service quality standards based on benchmarking results. 5) Ensure the stages of implementation, evaluate and revise quality standards according to benchmarking on an ongoing basis. 6) Establish quality indicators to achieve stakeholder satisfaction, productivity, and efficiency. 7) Internalizing the values and quality culture in the entire campus community. This research produces a strategy for implementing a comprehensive quality assurance system to build UIN Malang as the Center of Excellence and the Center for Islamic Civilization.
\end{abstract}

Keywords: Implementation, System, Assurance, Quality, Internal

\section{Introduction}

This study aims to analyse the implementation of the internal quality assurance system (IQAS/SPMI) in improving the quality of academic services at the State Islamic University (UIN) Maulana Malik Ibrahim Malang - East Java - Indonesia (called UIN Malang). This research is important to carry out to realize the effectiveness of one of the Government policies, namely improving the quality of higher education delivery in Indonesia since 2003. The implementation of IQAS is a process of implementing accountability and transparency of higher education which is carried out autonomously by the respective universities. This quality assurance is carried out based on Law number 12 of 2012 concerning Higher Education regarding the Higher Education Quality Assurance System (HEQAS/SPM-PT) which consists of the Internal Quality Assurance System (IQAS/SPMI), the External Quality Assurance System (EQAS/SPME), and licensing for the implementation of study programs. With details of its duties on the internal quality assurance system (IQAS/SPMI) which is managed by the relevant university and the external quality assurance system (EQAS/SPME) which is managed by an accreditation body from the government, in this case, the National Accreditation Board for Higher Education (NAB-HE/BAN-PT) or independent institutions outside governmentrecognized universities (Arifudin, 2019: 161-167; Mulyono, 2017, Hindaryatiningsih \& La Mashuri, 2020).

This study is increasingly important to carry out considering the number of tertiary institutions in Indonesia in quantity reaches around 4 thousand universities, while the number of tertiary institutions accrediting based on official data from the National Accreditation Board for Higher Education (NAB-HE/BAN-PT) is 2, 288 institutions. Of the 2,288 tertiary institutions that applied for accreditation to NAB-HE/BAN-PT, only 96 universities received an $\mathrm{A}$ accreditation rating, while a large number received a $\mathrm{B}$ rank and a $\mathrm{C}$ rank. By referring to these data, universities in Indonesia are still lagging even at the ASEAN regional level, especially if they have to compete with universities in the world in general. The results of various studies show that universities in Indonesia still have an inferior culture if they have to compete with universities in the world. This condition is homework that must be addressed concerning policies, institutional management, and university resources in general. There must be changes related to regulations to encourage universities towards good governance in carrying out their management processes. So that from year to year the number of good universities is increasing both in the group of public and private universities (Muh. Fitrah, Ruslan, Hendra, 2018: 78-86; Arifudin, 2019: 161-167). 
IQAS is a systemic activity of higher education quality assurance by each university independently to control and improve the implementation of higher education in a planned and sustainable manner (Kemenristekdikti, 2016: 21). According to Ahmad Sulaiman and Udik Budi Wibowo (2016:28) that IQAS in a university is an independent activity of the university concerned so that the process is designed, implemented, and controlled by the university itself without interference from the government. IQAS of Higher Education is run through several stages, namely the process of implementing internal quality assurance, self-evaluation, internal audit, and corrective action. This must be supported by the commitment and performance of the higher education process actors, as well as the organization of quality assurance institutions so that the quality control process can run effectively accompanied by positive quality evaluation results.

The quality of education in tertiary institutions should be an achievement of the vision, mission, and goals of higher education that are adjusted to the expected competencies of graduates, quality policies, and academic quality standards that have been set, and include aspects of input, process, and output based on professional values through the implementation of the three main missions of higher education in Indonesia) namely education and teaching, research, and community service.

Quality assurance agencies as IQAS actors must ensure that IQAS is implemented to ensure the quality of education through the implementation of the Three Main Missions of Higher Education (the popular term in Indonesia: Tri Dharma Perguruan Tinggi). IQAS also plays an important role in answering various problems related to education as well as a tool to analyze the challenges of higher education. Therefore, referring to the concepts described above, this paper will focus on the urgency of IQAS for improving the quality of higher education (Muh. Fitrah, Ruslan, Hendra, 2018: 78-86).

UIN Malang is one of the State Islamic Universities that has implemented the ISO 9001: 2000 Quality Management System (QMS) since 2008 which later developed into ISO 9001: 2008 and subsequently implemented ISO 9001: 2015. By implementing ISO 9001: 2015 Quality Management, UIN Malang is determined to prioritize quality in every process that occurs in every academic service, which has been compiled in Quality Standards starting from the input, process, and output. The standard set by the University is the standard used nationally, it's just that there are several integration contents that are the differentiator between UIN Malang and other universities (Sumbulah, 2017; Mulyono, 2015, 2017).

Based on the above rationale, the problem formulation proposed in this article is: "How is the strategy for implementing the internal quality assurance system (IQAS/SPMI) in improving the quality of academic services at UIN Malang?"

\section{Method}

This study used a qualitative method with a case study model (Denzin \& Lincoln, 1994: 2). The research design develops during the research process. Researchers collected data using techniques, namely: (1) in-depth interviewing, (2) observation, and (3) documentation (Moleong, 1990: 163-164).

Researchers conducted in-depth interviews with several key informants on campus, namely leaders at the rectorate level, leaders at the faculty level, and leaders at the department level, as well as managers at the Quality Assurance Institute (QAI/LPM) at the university level and the Quality Assurance Unit (QAU/UPM) at the faculty level. Researchers made observations of on-campus activities which included learning activities in class and outside the classroom, extracurricular activities in the campus environment. Researchers collected data through documentation, namely: primary, secondary, and supporting data sources. The primary document data for this study are books that serve as the University's academic guidelines. While secondary and supporting data, namely several other library documents as well as the results of downloads on the internet that support data and documents related to the research focus.

While the data analysis technique uses an interactive data analysis model referring to the opinion of Miles and Huberman (1992: 10-14). Data analysis takes place simultaneously which is carried out simultaneously with the data collection process, with the following stages: (1) data collection, (2) data reduction, (3) data display, and (4) conclusion drawing and verifying.

\section{Findings and Discussion \\ 3.1 Research Findings}

Based on the formulation of the proposed problem, namely, how to implement the internal quality assurance system (IQAS) in improving the quality of academic services at UIN Malang, it can be found as follows:

First, the University establishes institutions and units that are responsible for the quality assurance system for academic services, including 1) The University establishes the Quality Assurance Institute (QAI) which is responsible to the Rector and the Vice-Rector. 2) The Quality Assurance Institute carries out the Internal Quality Assurance System (IQAS) process, starting from system planning, document creation, implementation, and implementation of internal audits within the University. 3) The Faculty establishes the Quality Assurance Unit (QAU) of the Faculty, the Postgraduate Program establishes the Quality Assurance Unit (QAU) for the Postgraduate Program, the Language Development Center forms the Quality Assurance Unit (QAU) Language Development Center, and Ma'had (the Islamic campus dormitories) forms the Quality Assurance Unit Ma'had and the department/study program form the Quality Control Group (QCG) which is responsible to the Dean or Director or Chair. 4) Faculties, Postgraduate Programs, Language Development Centers, Ma'had, and 
Departments/Study Programs follow up by compiling a quality plan coordinated by the Faculty/Unit Quality Assurance Unit. 5) The Faculty Quality Assurance Unit, the Quality Assurance Unit of the Language Development Center, and the Ma'had Quality Assurance Unit check the achievement of quality objectives and reports it to the Dean and the Quality Assurance Institute. 6) Once every 6 (six) months the Quality Assurance Institute will carry out an Internal Audit activity. 7) The Internal Audit process is carried out on the scope of the University Quality Assurance System which occurs in all Study Programs/ Departments, Language Development Centers, and Ma'had. 8) The results of the Internal Audit will be processed by the Quality Assurance Information System sector to be reported to the Head of the Quality Assurance Institute. The Chairperson of the Quality Assurance Institute will provide reports and recommendations to the Chancellor based on the findings of the internal quality audit. The Chairman of the Quality Assurance Institute can also submit a request for corrective action to the Rector. 9) The Chancellor through the relevant Assistant Chancellor will instruct the Dean, Head of Department/Study Program, Chair of the Development Center, Director Ma'had to take corrective actions. Corrective action related to insufficient infrastructure and resources should be facilitated by the faculty, Postgraduate Program, Language Development Center (Arabic, English, Chinese), and Ma'had; meanwhile, inadequacies related to personal competence must be followed up by the faculty, where the faculty can cooperate with the Quality Assurance Institute. 10) The Training and Development field can also conduct training for lecturers or administrative staff upon the approval of the Assistant Rector's Request. 11) Field of Training and Development as well as the Faculty Quality Assurance Unit, Postgraduate Program, Language Development Center and Ma'had must evaluate/measure the impact of the corrective actions that have been taken. 12) Audit results, examination reports from the Faculty Quality Assurance Unit will be discussed in the Management Review Meeting (MRM/RTM). MRM is held jointly between the Faculties, Postgraduate Programs, Language Development Center, and Ma'had with the Quality Assurance Institute and leaders at the Rectorate level.

Second, compiling a system planning for UIN Malang academic service quality assurance through the following cycles: 1) Documents on Education Policy, Graduate Standards, and University Education Guidelines are made and determined to be implemented. 2) Documents on Quality Manuals, Quality Objectives for each department/study program/unit, Procedure Manual for each department/study program/unit, and Work Instructions for each department/study program/unit are made and then legalized for implementation. 3) Implementation using a footing against predetermined documents. 4) Monitoring is carried out to prevent/detect early errors that may occur in the process. 5) Measurement and self-evaluation is carried out by each department/study program/unit on the process that has been carried out. Measurement and self-evaluation are carried out to ensure that the system in the department/study program/unit is running according to the design. 6) Internal Quality Audit is conducted by the Quality Assurance Institute to find out various; a) constraints that occur in the implementation of the activity process in the department/study program/unit, b) Weaknesses of the planned system, c) Errors made in the implementation process. 7) Management Review Meeting (MRM) is conducted on the findings of the Internal Quality Audit to find a solution. 8) The cycle rotates continuously by emphasizing continuous improvement by showing best practices in the entire process.

Third, applying the PDCA model in the academic service quality assurance system at UIN Malang. Application of the PDCA (Plan, Do, Check, Action) model of the Total Quality Management (TQM) which will result in continuous improvement of the quality of academic services. PDCA implementation of TQM, namely: 1) Plan, there is a plan. 2) Do, the implementation of what has been planned. 3) Check, there is monitoring, examination, measurement, and evaluation of implementation and implementation results including the Internal Quality Audit. 4) Action, there is a follow-up and improvement of the evaluation results.

Fourth, setting the quality standards for academic services at UIN Malang including 1) at the university level, the Quality Assurance Institute (QAI) establishes Quality Assurance Guidelines for Faculties/ Departments/ Study Programs, and other educational programs (Postgraduate Program, Development Center Language, Ma'had), as well as units developed in UIN Malang. 2) QAI builds a commitment to carry out the quality assurance of higher education which it holds at each Faculty/ Department/Study Program, and other educational programs, as well as units developed in the UIN Malang environment. 3) QAI together with the Faculties / Departments / Study Programs, and other educational programs, as well as units developed in the UIN Malang environment, selects, and determines the quality standards it holds. 4) QAI determines and runs the organization and the working mechanism for quality assurance of departments/study programs, and other educational programs, as well as units developed in UIN Malang. 5) Faculties / Departments/Study Programs, and other educational programs, as well as units developed in the UIN Malang environment, carry out benchmarking (fulfilment of ideal status) the quality of their education on an ongoing basis.

Fifth, ensuring the stages of implementation of the academic service quality assurance system at UIN Malang, with the following flow: 1) The university sets its vision and mission. 2) Based on the vision and mission, each Faculty/Department/ Study Program, and other educational programs, as well as units developed within the UIN Malang, determine their respective visions and missions. 3) The vision of each Faculty/Department/Study Program, and other educational programs, as well as units developed in the UIN Malang environment, is then translated into a series of quality standards for each quality item as mentioned above. 4) Quality standards are formulated and stipulated by formulating the vision set and the needs of stakeholders. As a standard, the formula must be specific and measurable. 5) The university determines the organization and working mechanism of quality assurance. 6) The university carries out quality assurance by 
implementing quality control management. 7) The university evaluates and revises quality standards through benchmarking on an ongoing basis.

Sixth, to determine indicators of academic service quality at UIN Malang which include: 1) quality of input, 2) quality of the learning process; 3) quality of students to be served (customers), 4) quality of staff serving, 5) quality and priority in research, 6) financial resources and their use, 7) quality of graduates in national and international contexts. Included in the main part of the implementation of the academic quality assurance system is identifying the stakeholders of UIN Malang, namely: students, government, graduate employers, and the community. The success indicator of the implementation of the internal quality assurance system is the main means of measuring the extent to which UIN Malang has shown good performance, namely the achievement of stakeholder satisfaction, productivity, and efficiency.

Seventh, internalizing the value and quality culture in all lines and determining the consequences of opposing the establishment in UIN Malang academic services, by determining the following steps: 1) Opposing the establishment, this needs to be socialized considering that in general, the majority of staff are against change, especially if the change is to blame their performance. 2) Establish a joint commitment that efforts to improve the quality of academic services require more time, effort, and cost. 3) Instilling a common understanding that the quality assurance system involves the cooperation of all staff with direction, leadership, and genuine commitment from the management and allocation of adequate resources to achieve the desired quality of students and interested parties. This needs to be done to avoid the assumption that has developed so far that the academic service quality assurance system is solely the responsibility of the leadership and the Quality Assurance Institute (QAI). 4) Fostering an attitude of honesty and consistency towards all faculties, institutions, and units within the University to conduct self-quality assessments so that quality improvement efforts can be carried out continuously. This self-quality assessment is a self-improvement effort carried out by faculties, institutions, and each unit to increase the quality of service institutionally as well as trying to find or highlight the good or badness of each party. 5) The results of this self-quality assessment are then used by each faculty, institution, and unit to determine the priority for self-quality improvement with the full support of the top leaders of the university. 6) Implementation of the academic service quality assurance system at UIN Malang is aimed at almost all elements of the campus which include: policies and planning, procurement and development of Human Resources (HR), management and administration, students, program design, and development, curriculum design and courses, development of teaching materials, provision of facilities and infrastructure as well as learning media, learning assistance for students with special needs, as well as the assessment of student learning outcomes, and various other academic service efforts.

\subsection{Discussion}

The findings of the strategy for implementing the internal quality assurance system (IQAS/SPMI) in improving the quality of academic services at UIN Malang can be studied through the concept of the quality assurance process from the Directorate General of Higher Education (DGHE/DIKTI) the Ministry of National Education of the Republic of Indonesia (2003) which states that higher education quality assurance in the tertiary institution is run through stages which are arranged in a process as follows: 1) The college determines the vision and mission of the university concerned; 2) Based on the university's vision and mission, each study program determines the vision and mission of its study program; 3) The vision of each study program is then elaborated by the related study program into a series of quality standards for each quality item as mentioned above; 4) Quality standards are formulated and determined by concocting the university's vision (deductively) and the needs of stakeholders (inductively). As a standard, the formula must be specific and measurable, namely containing elements of ABCD (Audience, Behavior, Competence, Degree); 5) Higher education establishes the organization and working mechanism of quality assurance; 6) Higher education institutions carry out quality assurance by implementing quality control management; 7) Higher education institutions evaluate and revise quality standards through benchmarking on an ongoing basis. Furthermore, the Directorate General of Higher Education (2003) explains that higher education quality assurance in tertiary institutions can be carried out through various models of quality control management. One management model that can be used is the PDCA (Plan, Do, Check, Action) model which will result in continuous improvement or KAIZEN of higher education quality in tertiary institutions. Some of the principles that must underlie the mindset and action patterns of all PDCA-based quality control management actors are 1) Quality first: all thoughts and actions of higher education managers must prioritize quality. 2) Stakeholder-in: all thoughts and actions of education managers must be aimed at stakeholder satisfaction. 3) The next process is our stakeholder: everyone who carries out a task in the higher education process must consider other people who use the results of their duties as stakeholders who must be satisfied. 4) Speak with data: every person implementing higher education must take action and make decisions based on the analysis of the data they have previously obtained, not based on assumptions or engineering. 5) Upstream management: all decision-making in the higher education process is done in a participatory, not authoritative manner. The PDCA management model can be seen in the following figure: 


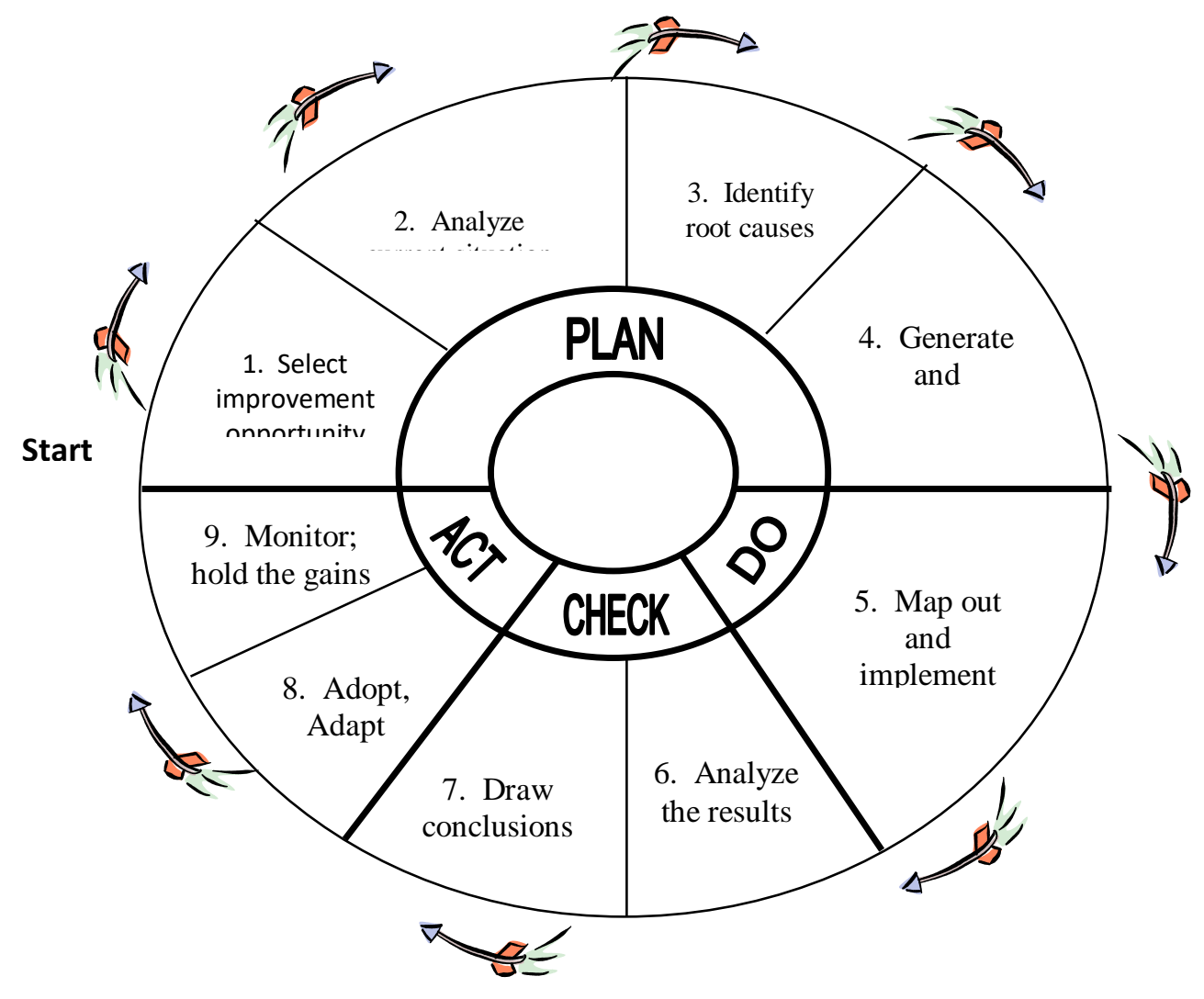

Picture 1. Plan-Do-Check-Act (PDCA) Cycle

In the 'check' stage of PDCA-based quality control management, there are quality checkpoints where each person implementing higher education must audit the results of the implementation of their duties with a predetermined quality standard. For example, the formative test that is carried out at the end of each subject is a quality control point in the learning process, which is carried out to audit whether the learning quality standards as formulated in the form of the Graduate Competency Standards (GCS/SKL) can be achieved. If the audit results turn out to be positive in the sense that they have reached the quality standard (QS in PDCA) as formulated in GCS, then in the next planning process or Plan (P in PDCA) the quality standard must be raised, so that higher education quality kaizen will occur, as illustrated in the picture above.

Meanwhile, if the results of the evaluation turn out to be negative in the sense that the quality standards as formulated in the Graduate Competency Standards (GCS/SKL) have not been or have not been achieved, then action must be taken immediately (A in the PDCA) so that the quality standard can be achieved. For example, if the Formative Test turns out to be below the GCS, the lecturer must do an Action (A in the PDCA) which can be in the form of repeating the discussion of related subjects until GCS can be achieved. Therefore, establishing quality checkpoints in each activity unit in PDCA-based quality control management is a condition sine qua non or a must.

Apart from these policies, the implementation of IQAS at UIN Malang and other universities in Indonesia such as Brawijaya University Malang also refers to the national accreditation instrument issued by the National Accreditation Board for Higher Education (NAB-HE/BAN-PT) and the Times Higher Education Supplement Quacquarelli Evaluation Instrument Symons (THES-QS) or AUN-QA as an international standard. So that the quality assurance scheme of several universities in Indonesia can be explained as follows:

1) Achieving the vision and mission through meeting quality standards utilizing continuous improvement (PDCA = Plan Do Check Act), using process-based management.

2) Customer satisfaction (customer satisfaction)

3) Customer satisfaction is maintained (customer care) for:

To run IQAS, the University implements steps called "quality assurance cycle", namely EDICF, which stands

1) Establish a quality assurance organization (E);

2) Develop a system (Policy, Document System (quality standard, quality manual, procedure manual, etc.) (D);

3) The system is implemented (socialization and work reference) (I);

4) Conducting the Internal Quality Audit (IQA). (one quality assurance cycle) (C); and

5) Follow-up (F). 
The Directorate General of Higher Education (2003: 20) provides instructions so that the strategy for implementing higher education quality assurance in tertiary institutions can be implemented, so several prerequisites must be met so that the implementation of quality assurance can achieve its objectives, namely: commitment, paradigm change, and mental attitude actors in the higher education process, as well as organizing quality assurance in tertiary institutions. Besides, for the implementation of higher education quality assurance in tertiary institutions to run gradually, the Directorate General of Higher Education (2003: 24) provides the following tips: 1) Hold workshops so that understanding, enthusiasm, and commitment to quality assurance grow; 2) Compiling a clear, detailed and realistic quality assurance plan; 3) Contact those who are competent in quality assurance as initial facilitators.

In the higher education management process carried out by the Internal Quality Assurance System (IQAS), it is not carried out for only 1 or 2 years but to maintain the quality of education it is carried out continuously. This is in line with the opinion of Hedwig \& Polla (2006) which states that quality assurance is a continuous routine work and must be carried out continuously and is not an ad hoc activity. Therefore, in the role of the Internal Quality Assurance System (IQAS) the monitoring and evaluation stages are carried out continuously by emphasizing that this activity is not looking for mistakes but to take continuous corrective action. The quality assurance system will produce college graduates who are competent, creative, innovative, and able to create jobs with the knowledge and technology they have as indicators of the success of quality higher education. With the rolling of new standards related to accreditation of both tertiary institutions and study programs, this is an effort to produce quality in education delivery. The orientation of this Regulation of the Minister of Research, Technology and Higher Education (2016) in Indonesia change is related to the achievement of the tri dharma which is explained in the achievement of the internal quality assurance system (IQAS).

Planning for an internal quality assurance system (IQAS) is carried out through several strategies. The planning preparation strategy refers to the vision, mission, and goals of each university. Besides, the policy for compiling the internal quality assurance system (IQAS) program based on the phenomena and facts in the tertiary institution and society shows that the internal quality assurance system (IQAS) must continue to change according to the needs of the times and the demands of accreditation.

This must be a commitment to a policy with a management approach to the internal quality assurance system (IQAS) which shows that universities are very focused on paying attention to any quality manual needs related to improving the implementation of the education process. To achieve these goals, universities must take strategic steps that support their implementation. These strategic steps become indicators that have an impact on changes in the internal quality assurance system (IQAS) process in the tertiary institution itself. The planning process is in the form of an integrated model and supplements, with an internal quality assurance system (IQAS) with an educational management approach. (Arifudin, 2019: 161-167).

Based on the findings and discussion, the research findings model is outlined as follows:

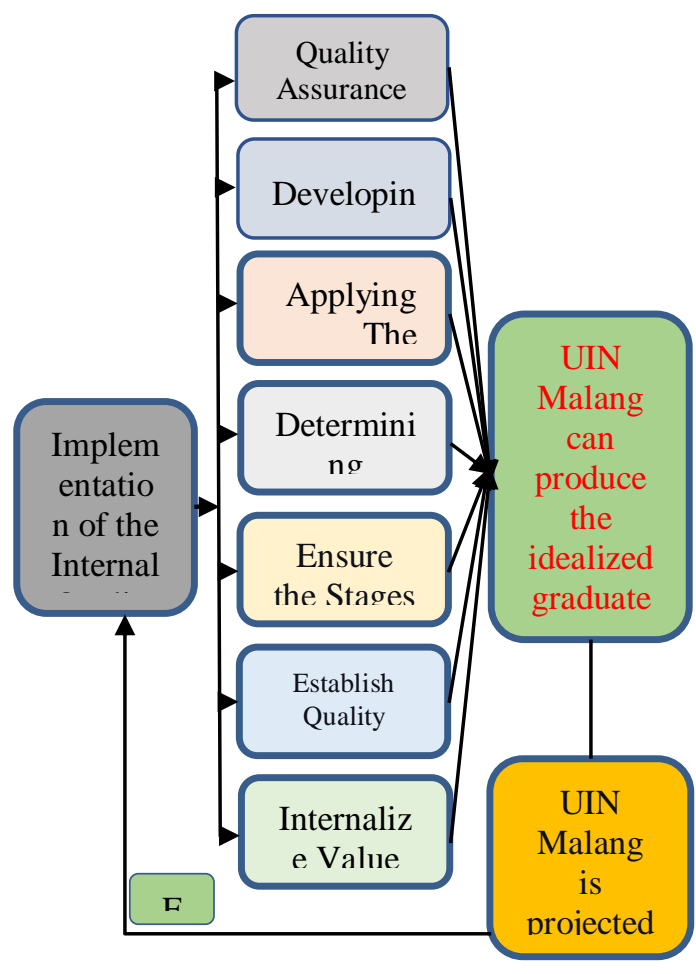

Figure 2. Implementation of the 


\section{Conclusion and Suggestions}

From the findings and discussion of strategies for implementing the academic service quality assurance system at UIN Malang through the following stages: 1) In implementing academic service quality assurance, University established the Quality Assurance Institute $(\mathrm{QAI} / L P M)$ which is responsible for the Rector and ViceRector. 2) The Quality Assurance Institute carries out a quality assurance system process, starting from system planning, document preparation, implementation, and implementation of internal quality assurance within the University. 3) Faculties, Postgraduate Programs, Language Development Centers, and Ma'had establish a Quality Assurance Unit (QAU/UPM) which is responsible to the Dean or Director or Chair. 4) Faculties, Postgraduate Programs, Language Development Centers, and Ma'had follow up by compiling a quality plan with the Faculty-level Quality Assurance Unit as the facilitator. 5) The Quality Assurance Unit of the Faculty, Postgraduate, Language Development Center, and Ma'had checks the achievement of quality objectives and reports it to the Dean and the Quality Assurance Institute. 6) Once every 6 (six) months the Quality Assurance Institute will carry out an Internal Audit activity. 7) The Internal Audit process is carried out on the scope of the University Quality Assurance System which occurs in all Study Programs/ Departments, Language Development Centers, and Ma'had. 8) The Quality Assurance Information System Unit processes the results of the internal audit which are then reported to the Head of the Quality Assurance Institute. 9) The Chairperson of the Quality Assurance Institute will provide reports and recommendations to the Rector based on the findings of an internal quality audit, the Chair of the Quality Assurance Institute can also submit a request for corrective action to the Rector. 10) The Rector, through the relevant Vice-Rector, will order the Deans, Departments/Study Programs, the Head of the Language Development Center (Arabic, English, Chinese), and Ma'had to take corrective actions. Corrective actions related to insufficient infrastructure and resources must be facilitated by Faculties, Postgraduate, Language Development Centers and Ma'had; meanwhile, inadequacy related to personal competence must be followed up by the faculty, where the faculty can cooperate with the Quality Assurance Institute. 11) The Training and Development field can also conduct training for lecturers or administrative staff with the approval/request of the Vice-Rector. 12) The field of Training and Development and the Quality Assurance Unit of the Faculty, Postgraduate, Language Development Center, and Ma'had must evaluate/measure the impact of the corrective actions that have been taken. 13) Audit results, inspection reports from the Faculty Quality Assurance Unit will be discussed in the Management Review Meeting (MRM/RTM). MRM is held jointly between the Faculties, Postgraduate, Language Development Center, and Ma'had with the Quality Assurance Institute and the Rector. 14) The leadership of the University through the Quality Assurance Institute continuously provides directions so that the implementation of quality assurance of academic services can be carried out properly so that commitment, paradigm change, and mental attitude of the campus community are grown, and supported by solid quality assurance organizations at all levels. 15) The Quality Assurance Institute (QAI) internalizes the value and culture of the quality of academic services through the following tips: a) Develop a clear, detailed, and realistic quality assurance plan; b) Organizing socialization, training, and workshops to grow understanding, enthusiasm, and commitment to quality assurance; c) Coordinate with competent parties in quality assurance as facilitators, in this case, SGS ISO 9001: 2000 which then continues to ISO 9001: 2008 than ISO 9001: 2015.

This study produces an implementation model of the Internal Quality Assurance System (IQAS/SPMI) to improve the quality of academic services which is useful for ensuring as well as controlling the standards set by the higher education management. The quality assurance system model is needed to measure the success rate of academic services and increase the expected competence of graduates in every academic service in higher education.

Through the implementation of this academic service quality assurance system, basic data on strengths, weaknesses, and weaknesses in academic services that have been organized by universities will be obtained. The growth of the value and culture of the quality of academic services will be used as benchmarks to improve, improve the performance of the University's academic management to realize its vision and mission, not just a vision and determination that is explicit but has been implemented in all campus activities. With the application of IQAS, in this case, UIN Malang can produce idealized graduates called Ulul Albab Profile, namely ulama' who are professional intellectuals and/or professional intellectuals who are ulama' and in the future, UIN Malang is projected to become The Center of Excellence and The Center for Islamic Civilization.

\section{References}

1. Arifudin, Opan. (2019). Management of the Internal Quality Assurance System (IQAS/SPMI) as an Effort to Improve the Quality of Higher Education, MEA Scientific Journal (Management, Economics, \& Accounting), Volume 3 No. January 1 - April 2019, 161-167.

2. Arintasuta, I Ketut Ngurah \& Agoes Ganesha Rahyuda. (2020). The Effect of Transformational Leadership, Work Ethics, and Work Motivation on Employee Performance at Universitas Pendidikan Ganesha (Undiksha) Singaraja. International Journal of Scientific \& Engineering Research, Volume 11, Issue 6, June-2020, ISSN 2229-5518, IJSER @ 2020, http://www.ijser.org, 201-204.

3. Baharuddin. (2004). "UIN Realizes the Establishment of the Establishment of the Ulul Albab Community" in M. Zainuddin, et al., Combining Science and Religion Towards the University of the Future. Malang: Bayumedia. 
4. Denzin, Norman K., \& Yvonna S. Lincoln. (1994). "Introduction: Entering the Field of Qualitative Research.” In Norman K. Denzin and Yvonna S. Lincoln (Eds.) Handbook of Qualitative Research. Thousand Oaks: Sage Publications.

5. Directorate General of Higher Education, Ministry of National Education. (2003). Guidelines for Higher Education Quality Assurance. Jakarta: Directorate General of Higher Education, Ministry of National Education.

6. Directorate General of Higher Education, Ministry of National Education. (2010). Quality Assurance System for Higher Education I (QASHE/SPMPT). Jakarta: Directorate General of Higher Education, Ministry of National Education.

7. Government of the Republic of Indonesia. (2003). Law of the Republic of Indonesia Number 20, 2003 concerning the National Education System.

8. Government of the Republic of Indonesia. (2012). Law Number 12 Year 2012 concerning Higher Education.

9. Hedwig, R. \& Polla, G. (2006). The Quality Assurance System Model and Its Implementation Process in Higher Education. Yogyakarta: Graha Ilmu.

10. Hindaryatiningsih, Nanik. \& La Mashuri. (2020). Development of Quality Management Model of Elementary School Principal Academic Supervision in Kendari City, International Journal of Scientific \& Engineering Research Volume 11, Issue 6, June-2020 296, ISSN 2229-5518, IJSER (C) 2020, http://www.ijser.org, 296-301.

11. http://umm.tp.ugm.ac.id/, Training of Higher Education Quality Management System Based on ISO 9001: 2008, [Online] Saturday, March 5, 2016: 07.50.

12. M. B. Miles, \& A. M. Huberman. (1992). Qualitative Data Analysis: A Resource Book on New Methods, Translators: Rohidi, T.R. Jakarta: UI Press.

13. Mahendra, Rendi. (2016). 10 Ways to Improve Implementation of ISO 9001: 2015, May 26, 2016, [Available] https://isoindonesiacenter.com/, [Online] Tuesday, 30 June 2020: 14.27.

14. Mansur, Rosichin. (2009). Campus A Cultural Center, 10 June 2009, [Available] https://rosichin.wordpress.com/, [Online] Tuesday, March 22, 2016: 14.23.

15. Moleong, Lexy J. (1990). Qualitative Research Methods. Bandung: Remaja Rosda Karya.

16. Moleong, Lexy J. 1990. Qualitative Research Methods. Bandung: Remaja Rosda Karya.

17. Muh. Fitrah, Ruslan, Hendra. (2018). Urgency of Internal Quality Assurance System for Higher Education Quality Improvement, Journal of Quality Assurance Institute for Quality Assurance Institute of Hindu Dharma Negeri Denpasar, Volume 4 Number 1 February 2018, ISSN: 2407-912X (Print), ISSN: 2548-3110 (Online), http://ejournal.ihdn.ac.id/index.php/JPM, p. 78-86

18. Mulyono \& Wekke, I. S. (2018a). Academic and Culture Development Strategy Management for Islamic Higher Education in Indonesian. In IOP Conference Series: Earth and Environmental Science (Vol. 175, No. 1, p. 012163). IOP Publishing.

19. Mulyono \& Wekke, I. S. (2018b). Religious and Academic Cultural in Technology Development on Islamic Higher Education of Indonesia. International Journal of Pure and Applied Mathematics, 119 (18), 1093-1105.

20. Mulyono. (2017). Rationale for Implementing ISO 9001: 2008 Quality Management System at FITK UIN Malang, J-MPI (Journal of the Islamic Education Management), Vol 2, No 1, 2017, 61-68

21. Munir al-Ba'labakki. (1974). al-Maurid. Beirut: Dar al-Ilm li al-Malayin.

22. Perbanas Institute Administrator, Grand Launching Implementation of ISO 9001:2008, Wednesday, April 11, 2012, http://www.perbanasinstitute.ac.id/, [Online] Saturday, March 5, 2016.

23. Sahlan, Asmaun. (2014). Enhancement of Culture in Education: Research on Indonesian High School. Journal Procedia: Social and Behavioral Sciences 143 (2014), 117-121.

24. Samudi. (2013). Efforts to Improve Academic Culture in Higher Education, Thursday, October 10, 2013, STAI La Tansa Mashiro Rangkasbitung, [Available] http://samudi-mpd.blogspot.co.id/, [Online] Monday, March 21, 2016: 00.44.

25. Shahril Bin Ahmad Razimi and Sidek Baba. (2013). Integrating Ulul Albab Education and Science Education in Development Insan Ta'dibi Generation: A Case Study of Mara Junior Science College (MJSC). Antalya, Turkey: WEI International Academic Conference Proceedings, January 14-16, 2013, 96-103.

26. Subirin, Nor Adzimah., Nor Hayati Alwi, Fathiyah Mohd Fakhruddin, Umi Kalthom Abdul Manaf and Siti Suria Salim. (2017). Ulul Albab Generation: Roles of Ulul Albab Teachers in Malaysian Selected School. International Journal of Academic Research in Business and Social Sciences Vol. 7 [10221031], Special Issue - 4th International Conference on Educational Research and Practice 2017 ISSN: 2222-6990.

27. Suhaimi, M. \& Yusof I. (2013). Developing the Ulū Al - Albāb Model for Sustainable Value and Wealth. International Journal of Business and Law, 2(1), 28-34.

28. Sumbulah, Umi. (2017). De-radicalisation of Indonesian Students: A Case Study of UIN Malang, Pertanika Journal of Social Sciences \& Humanities, published by Universiti Putra Malaysia Press, Vol. 25 (S) Aug. 2017, 155. 
Mulyono $^{\mathrm{a}}$, Asmaun Sahlan ${ }^{\mathrm{b}}$, Tutut Sholihah ${ }^{\mathrm{c}}$, Diah Rusmingsih $^{\mathrm{d}}$, Efy Setiawati Atanjuani $^{\mathrm{e}}$

29. Tarbiyah Study Center of Ulul Albab UIN Maulana Malik Ibrahim Malang. (2010). Tarbiyah Ulul Albab Tracing Traditions to Form a Person. Malang: UIN-Malang Press Malang.

30. The Curriculum Development Team of UIN Maulana Malik Ibrahim Malang. (2016). The Standard Ulul Albab Curriculum Based on KKNI. Malang: UIN Maulana Malik Ibrahim Malang, 21 June 2016, 25-28.

31. Umi Kalthom Abdul Manafa, Fadzilah Abdul Rahmana, Fathiyah Mohd Fakhruddina Siti Solehah Ibrahim. (2017). Characteristics of Students' Personality for An Ulul Albab Program Student Intake in Malaysia. Social Science, Education and Humanities Research, volume 115, 3rd International Conferences on Education in Muslim Society (ICEMS 2017), 253 -259.

32. Universitas Islam Negeri Maulana Malik Ibrahim Malang. (2009). Tarbiyah Uli al-albab: Dhikr, Fikr, and Shaleh Charity - The Concept of Education of Maulana Malik Ibrahim State Islamic University Malang. Malang: UIN Malang.

33. Wahab, A. Azis. and Dyah Kusumastuti. (2009). Reflections on Quality Assurance / Application of Quality Management Systems in Education. Bandung: Education Administrative Doctoral Program of UPI Bandung.

34. Wirakartakusumah, Aman. (1999). Reform of Islamic Education in Higher Education: Vision, Mission, and Strategy, in Fuaddudin \& Cik Hasan Bisri (Eds), The Dynamics of Islamic Thought in Higher Education. Jakarta: Logos Wacana Ilmu.

35. Zulkifli Mohamad al-Bakri. (2006). Ulul Albab: Concept and Understanding According to Sharak. Terengganu: Majlis Agama Islam Dan Adat Melayu Terengganu (MAIDAM). 